\title{
Exchange Rate and Foreign GDP Elasticities of Swiss Exports Across Sectors and Destination Countries*
}

\author{
Sandra Hanslin Grossmann ${ }^{\dagger}$, Sarah M. Lein ${ }^{\ddagger}$ and Caroline Schmidt ${ }^{\S}$
}

February 2016

\begin{abstract}
This paper uses a detailed breakdown of Swiss trade flows to identify how the impact of the two main determinants of Switzerland's exports - foreign demand and the real exchange rate - varies across sectors and export destinations. Our main findings are that i) both foreign demand and exchange-rate elasticities vary substantially across both export sectors and export destinations. ii) Foreign demand trends are more important for structural considerations than the exchange rate. This is due to the fact that exports of the two largest export sectors are relatively sensitive to long-run foreign demand developments while they are relatively insensitive to changes in the exchange rate. iii) The sectoral structure of Switzerland's exports has shifted towards goods that have a lower short-run demand elasticity and a higher long-run demand elasticity. Goods exports are thus less influenced by business cycle fluctuations while they benefit more from long-term growth trends, in particular in emerging markets. This has been a major contribution to the boom in Swiss exports during the 2000s. iv) The export share of sectors with a relatively low exchange rate elasticity has increased. However, this result is mainly driven by the strong rise in exports of chemicals and pharmaceuticals as well as precision instruments and watches, which are also the two important sectors responsible for the Swiss trade surplus.
\end{abstract}

JEL classification: F14, C33.

Keywords: Exports, Switzerland, Foreign Demand Elasticities, Exchange Rate Elasticities.

\footnotetext{
*We thank Matthias Lutz, Attilio Zanetti and an anonymous referee for many helpful comments and suggestions. The views expressed in this paper do not necessarily reflect those of the Swiss National Bank.

†Swiss National Bank, Börsenstrasse 15, CH-8022 Zurich, Switzerland, E-mail: Eandra.hanslin $\left(a_{\text {snh.ch }}\right.$

${ }^{\ddagger}$ University of Basel, Peter-Merian-Weg 6, CH-4002 Basel, Switzerland, E-mail: sarah.lein(a)mibas.ch

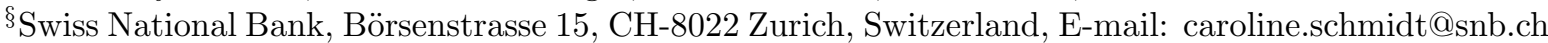




\section{Introduction}

This paper explores the sensitivity of Switzerland's goods exports to their main determinants, income and prices, both across sectors and export destinations. ${ }^{\text {I }}$ Despite weak foreign demand and the huge appreciation of the Swiss franc, Switzerlands exports showed quite some resilience since the onset of the financial crisis. However, there were remarkable differences across export destinations and sectors. Exports to Emerging Asia, for instance, collapsed much less in 2009 than exports to Europe. Across sectors, exports of metals and machinery dropped strongly, while pharmaceuticals declined only little.

Estimating Swiss export elasticities at the disaggregate level helps us to understand why exports were affected quite differently across export destinations and sectors since the start of the financial crisis. Also, with disaggregate estimates it is possible to derive systematic patterns across commodities and countries.

Our study is related to a large body of empirical trade literature, reflecting the huge interest in understanding how trade volumes are affected by changes in their main determinants. Seminal contributions include Houthakker and Magee (एप6.), Goldstein and

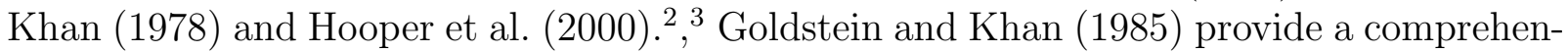
sive survey on the empirical trade literature until the mid 80 s. $^{\text {⿴囗 T }}$ The studies surveyed by Goldstein and Khan analyse demand and/or supply as well as price elasticities of exports and/or imports with alternative variable specifications, modelling approaches as well as data sets (time spans, data frequency and country sample). There are three robust findings: First, the estimates for long-run price-elasticities of demand for imports and exports on average exceeds unity, whereas the short-run price-elasticity is considerably smaller. Second, long-run income elasticities for industrialised countries fall in the range of 1 to 2 , while the short run income elasticity is generally higher. Third, the (few) studies which use more disaggregate data show that there exist significant differences in both price and income elasticities across commodity groups (sectors), and that some regularities exist. I.e. it seems that manufactured goods exhibit a higher price elasticity than non-manufactured goods.

Evidence of dispersion also exists for estimates across export destinations. Marquez (먹) estimates bilateral trade elasticities for 7 countries (in total 56 equations) and finds a significant dispersion in bilateral trade elasticities. While the dispersion of disaggregate

\footnotetext{
${ }^{1}$ In this paper, income is proxied by foreign GDP while the relative price is proxied by a measure of the real exchange rate.

${ }^{2}$ Houthakker and Magee (एप6प) analyse both demand and price elasticities of exports and imports for a set of 26 countries in order to predict trade balance developments. Their sample also includes Switzerland, where they find an income elasticity of 1.47 and a price elasticity of -0.58 .

${ }^{3}$ Hooper et al. (2000) estimates both short and long-run income and price elasticities of aggregate exports for the G7-countries.

${ }^{4}$ For more recent insights to estimating trade elasticities see Marquez (एण02).

${ }^{5}$ Note that this is supporting evidence for the J curve.

${ }^{6}$ Note that with considerable differences between the income elasticities of exports and imports for a given country, this implies a continuous trend in the trade balance if the country grows at the same rate as its trading partners.
} 
trade elasticities is informative itself, it is relevant for aggregate trade elasticities, too. As shown by 0 rcutt ([.5.5) , aggregate estimates may be biased to the downside, in particular if the variance of disaggregate estimates is high. This is particularly true for estimates of price elasticities, and is generally referred to as the estimation bias.

In addition to the international literature on the determinants of trade, our analysis is also related to previous work on Swiss exports. For aggregate Swiss exports, the Swiss State Secretariate of Economic Affairs $\mathbf{B E C O}(2010)$ estimates both short- and long-run demand and exchange-rate elasticities. They find that the short-run demand elasticity is much higher than its long-run elasticity. On the contrary, the sensitivity of exports to variations on real exchange rates is lower in the short compared to the long run. Looking at disaggregate data, Lamla and Lassmann (201]) estimate exchange rate and demand elasticities for all 12 export sectors and six destination countries. They find that for the three most important export sectors (chemicals incl. pharmaceuticals; machinery; precision instruments, watches and jewellery) the exchange rate elasticity is modest, while demand elasticities are relatively substantial. Abrahamsen andSimmons-Siien (खणU) look at Swiss exports of metals and machinery to 10 export destinations. Their results suggest that exports of metals and machinery to the euro area and especially to Germany react strongly to exchange rate movements whereas exports of those goods to the US, UK and Canada react relatively little. Auer and Sauré $(2011,2012)$ examine exchange rate and demand elasticities with even more disaggregated trade data (approximately 865 goods categories). In Amer and Sawre ( 200 ) exporter/importer demand elasticities and bilateral exchange rate elasticities are estimated with annual data for good-specific, bilateral exports in a panel of 24 OECD countries for the time period 1972 to 2000. The exchange rate elasticity that they obtain for Switzerland's exports is the lowest for all countries, followed by Japan and Sweden. Concerning the demand elasticity, Switzerland is also below average. ${ }^{\boldsymbol{}}$ In a companion paper, Awer and Sawre (एणㄱ) investigate Switzerland's top 30 export products (covering around 40\% of Switzerland's exports) using quarterly data for the 2005Q1 2010Q3 period. They find that the appreciation of the Swiss franc in 2009/10 has had a pronounced negative effect on Swiss export performance, but that this was partly masked by the concurrent recovery in global demand.

Compared to these recent studies on Swiss exports, we enhance the scope of the analysis threefold. First, we broaden the set of countries included and estimate a panel regression with quarterly data from 1989Q1 to 2014Q4. The analysis incorporates 24 major export destinations (selected on the basis of data availability) and all 12 major sectors. Second, we distinguish between long- and short-run changes in both demand and exchange rates using an error-correction approach for each sector and country. Third, we systematically document the main regularities of the estimated demand and exchange rate elasticities across countries and sectors.

\footnotetext{
${ }^{7}$ See also एesaran_and Smith (एप.95) and Щmbs and Mejean (एण5).

${ }^{8}$ Note that the estimation approach yields a single global elasticity for each good (assumed to be the same for each country). The elasticity for a given country is then obtained by multiplying the global elasticity for each good by the share that good has in this country's exports. Overall, the dispersion of the resulting exchange rate elasticities is not very large.
} 
We find that the long-run sensitivity of exports to changes in foreign demand, as proxied by the change in foreign GDP is larger than one. That is, a one percent increase in foreign GDP (foreign demand and foreign GDP is used interchangeably in this paper) raises Swiss exports by more than one percent on average. This is in line with the empirical findings in the literature discussed above. Regarding the price elasticity, a one percent increase in the real exchange rate (i.e. an appreciation) decreases exports by less than one percent. This is in line with other estimates for Switzerland (see e.g. Houthakker and Magee ([96.9), Senjadji and Montenegro (एप9g9) and Awer and Sawre (एण) ), but somewhat lower than a broader country average.

Moreover, the disaggregated data reveal that there are significant differences across sectors and export countries. While sector-specific effects explain a substantial part of the variation in exchange rate elasticities, both sectoral and destination characteristics are important to explain demand elasticities. We rank sectors according to their exchange rate and long-run demand elasticities and find that exports of the two largest export sectors (chemicals incl. pharmaceuticals as well as precision instruments and watches) are relatively sensitive to long-run foreign demand developments, while they are relatively insensitive to changes in the exchange rate. Furthermore, we can identify destination specific patterns for long-run demand elasticities. In particular, Swiss exports to emerging countries exhibit significantly higher long-run demand elasticities than exports to other destinations. We also find that sectors that have grown in terms of their share in total exports are those with high long-run demand elasticities and lower short-run demand elasticities. At the same time, the shares of sectors with relatively low exchange rate elasticities have increased. Overall, our results suggests that foreign demand trends (in particular in faster growing emerging countries) are more important for structural considerations of Swiss exports than foreign business cycle fluctuations and the exchange rate. However, given the unprecedented extent of both the business cycle and the exchange rate shocks, Swiss exports nonetheless were hit hard in the recent crisis and are still struggling to return to pre-crisis growth rates.

Our paper is organized as follows. In the next section we describe the data and the estimation approach. Section 0 discusses the estimated elasticities and their dispersion

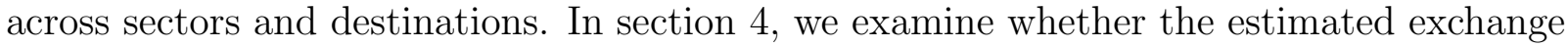
rate and demand elasticities exhibit systematic patterns at the sectoral and country level and assess how these elasticities correlate with the structural composition of Swiss exports. Section [ [ concludes.

\section{Dataset and estimation approach}

\subsection{Data}

Our analysis is based on quarterly trade data provided by the Swiss Federal Customs Administration (FCA) covering the period from 1989Q1 to 2014Q4. For the disaggregated analysis we use data on sector-specific goods exports from Switzerland to the 24 most im- 
portant destination countries. ${ }^{\mathbf{9}}$ Together these markets cover around $83 \%$ of Switzerland's exports. Table $\square$ in Appendix lists the countries in the sample and the corresponding export share; Table $\boldsymbol{\nabla}$ in Appendix lists the 12 sectors. Nominal exports (both total and across countries) are deflated by the export deflator from the national accounts while sectoral exports are deflated by sector-specific deflators (i.e. the subcomponents of the national accounts deflator). The resulting real export series are then seasonally adjusted. Foreign demand is proxied for by respective aggregate GDP. ${ }^{\mathbf{W}}$ Quarterly seasonally-adjusted real GDP of the 24 importer countries is taken from the national statistical agencies. If official GDP series do not exist back to 1989, they are extended by data from Oxford Economics. To compute bilateral sectoral real exchange rates we multiply bilateral nominal exchange rates by the sector specific domestic deflator (i.e. unit values) and divide it by the foreign CPI. ${ }^{\square}$ All data are in logs.

\section{$2.2 \quad$ Estimation approach}

To estimate demand and exchange rate elasticities of Swiss exports, we use an errorcorrection model. The model allows us to estimate the long-run elasticities while simultaneously accounting for transitory movements in exports, for instance related to supply constraints, inventory adjustments or weather-related effects (Hooper et al., 20001). Panel cointegration tests (as suggested by Persyn and Westerlund (2008)) show that exports, foreign demand and the real exchange rate are cointegrated of order one. The results of the panel cointegration tests are reported in the Appendix $1.2 .{ }^{\mathbb{D}}$ The estimated equation thus reads:

$$
\Delta \exp _{j i t}=\alpha_{j i}-\lambda_{j i}\left(\exp _{j i t-1}+\beta_{j i}^{l r} r e r_{j i t-1}-\gamma_{j i}^{l r} g d p_{i t-1}\right)-\beta_{j i}^{s r} \Delta r e r_{j i t-1}+\gamma_{j i}^{s r} \Delta g d p_{i t-1}+\varepsilon_{j i t}
$$

where $\exp _{j i t}$ denotes the volume of exports in sector $j$ to country $i$ at time $t$, rer denotes the real exchange rate, $g d p$ is foreign demand, $\alpha$ is a sector- and country-specific constant, and $\varepsilon$ the error term, which is assumed to be iid normal with mean zero and variance $\sigma_{\varepsilon}^{2}$. The speed of convergence to the long-run equilibrium is captured by $\lambda$, and the long-run elasticities of exports to the exchange rate and foreign demand are captured by $\beta^{l r}$ and $\gamma^{l r}$, respectively. Analogously, the short-run elasticities are captured by $\beta^{s r}$ and $\gamma^{s r}$. Note

\footnotetext{
${ }^{9}$ We look at goods exports only as for services there is no country disaggregation available.

${ }^{10}$ To better understand export developments during the great trade collapse, it might have been even more helpful to use import-adjusted measures of aggregate demand components instead of foreign GDP

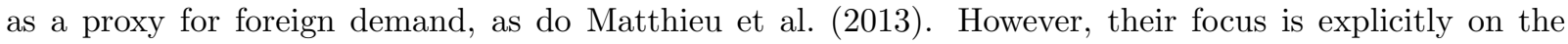
determination of imports while we focus on Swiss exports. Also, this approach would have been beyond the scope of our analysis.

${ }^{11}$ As a robustness check we have also tried a PPI-based real exchange rate which gives similar results.

${ }^{12}$ Please note that our main goal is to provide a comprehensive picture of all sectors and many countries (12x24). The drawback is that we have to do without single tests of each of the 288 equations. Hence, insignificant estimates of the elasticities are obviously possible.

${ }^{13}$ Note that exports and the real exchange rates are both sector and destination specific. Foreign demand differs only across destinations and not across sectors.
} 
that we set the signs in equation (1) such that all coefficients should (a priori) be positive. Hence, a positive estimate of $\beta$ implies that a real appreciation affects exports negatively.

There is a consensus in the empirical trade literature that foreign demand and a relative price measure are the two main determinants for exports. However, there is also a debate on whether the exchange rate volatility affects exports. ${ }^{\mathbb{4}}$ As the effect of volatility is not in our focus, we stick to the standard equation in the paper. However, we did some robustness checks. In Section 15 we show how our elasticities change when we take the exchange rate volatility into the long-run relationship.

As a benchmark, we start by estimating the model using aggregate data. Total Swiss exports are regressed on the aggregate real exchange rate (CPI-based and export-weighted against 40 trading partner) and aggregate foreign demand (an export-weighted world GDP ${ }^{\mathbb{3}}$ covering around $82 \%$ of Switzerland's exports).

Then, we disaggregate the data step by step. This allows us to examine the effects of disaggregation along the two dimensions of interest, countries and sectors, on the estimated demand and exchange rate elasticities. In a first step, we disaggregate the data across countries and estimate a panel model for exports, where the cross-sectional dimension is countries (that is, the dimension $j$ in equation $(\mathbb{\mathbb { C }})$ is discarded). We use a mean group estimator (ए)saran et ad, एप9g9). This basically estimates time-series models for each country and then averages the panel coefficients across countries.

In the final step, we estimate one time-series model for each sector and each country separately. Thus, both subindices $i$ and $j$ in equation $(\mathbb{\square})$ are relevant. This model incorporates the maximum degree of heterogeneity, because it allows for both cross-sectoral and cross-country variations. The results are reported in terms of weighted (according to export shares) averages.

Note that in the following tables and figures we use the term $\mathrm{rer}^{l r}\left(\mathrm{rer}^{s r}\right)$ to denote the long-run (short-run) exchange rate elasticity and the term $g d p^{l r}\left(g d p^{s r}\right)$ for the long-run (short-run) foreign GDP elasticity.

\section{Results}

This section presents the estimates for exchange rate and foreign-demand elasticities and documents their heterogeneity across sectors and destination countries.

\subsection{Swiss goods exports elasticities}

Are Swiss exports more or less sensitive to foreign demand and exchange rate shocks than the exports of other countries? As a benchmark and to compare with estimates for

\footnotetext{
${ }^{14}$ One of the first contributions which considers effects from exchange rate expectations is Warner and

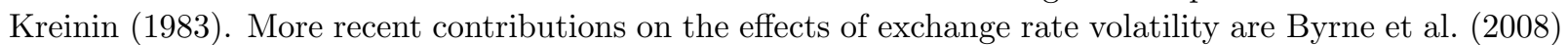
and Jaussaud and Rey (एण2).

${ }^{15}$ This measure includes the United States, the euro area, United Kingdom, Japan, China, South Korea, Taiwan, Hong Kong, Singapore, India, Brazil and Russia.
} 
other countries, we compute Swiss short and long-run foreign demand and exchange rate elasticities at the aggregate level.

Table [ , column 1, provides the estimation results for the benchmark model using aggregate data. The long-run exchange rate elasticity amounts to 0.65 ; the short-run elasticity is much smaller (in absolute terms) with 0.17. In contrast, the long-run demand elasticity (1.52) is much smaller than the short-run elasticity (3.10). As pointed out in the introduction, a lower short-run to long-run exchange rate elasticity, and a higher short-run to long-run income elasticity re in line with the literature. Regarding the absolute size, our estimate of the exchange rate elasticities seems to be rather a little lower compared to what is documented for many countries. ${ }^{\text {W }}$ However, compared to Hooper et al. (2000), who uses a similar approach to estimate short- and long-run elasticities, our estimate of the exchange rate elasticities are very much in line with the ones he finds for the G7countries. At the same time, none of the countries included in Hooper et al. (20000) comes close to our estimated short-run income elasticity of 3.1. Even when we adjust the sample period to 1981 to 2000 to match better the Hooper et al. (2000) results, we still obtain a comparatively high short-run demand elasticity of 2.8 for Switzerland.

Table 1: Disaggregate and aggregate estimates

\begin{tabular}{lccc} 
& Total exports & Mean Group & Sectoral average \\
\hline$r e r^{l r}$ & $0.65^{* * *}$ & $0.77^{* * *}$ & $0.76^{* * *}$ \\
& $(0.22)$ & $(0.06)$ & $(0.44)$ \\
$g d p^{l r}$ & $1.52^{* * *}$ & $1.60^{* * *}$ & $1.29^{* * *}$ \\
& $(0.11)$ & $(0.17)$ & $(1.20)$ \\
$r e r^{s r}$ & $0.17^{* *}$ & $0.64^{* * *}$ & $0.64^{* * *}$ \\
& $(0.07)$ & $(0.03)$ & $(0.07)$ \\
$g d p^{s r}$ & $3.10^{* * *}$ & $1.35^{* * *}$ & $1.50^{* *}$ \\
& $(0.32)$ & $(0.18)$ & $(1.42)$ \\
$\lambda_{j i}$ & $0.15^{* * *}$ & $0.28^{* * *}$ & $0.21^{* * *}$ \\
& $(0.06)$ & $(0.03)$ & $(0.06)$ \\
\hline Method & Time Series & Panel & Panel \\
Estimated by & - & Country & Country and sector
\end{tabular}

Note: The table shows estimation results for the different models. Coefficients are reported with standard errors in parentheses which are clustered in columns (2) and (3). Significance levels are denoted by *** $=p<0.01{ }^{* *}=p<0.05 ;^{*}=p<0.1$. For the sectoral average, the significance level refers to the weighted average of individual t-values while the standard errors reported are weighted averages of standard errors. The cointegration relationship of the aggregate estimation (column (1)) contains a trend from 1997 onwards.

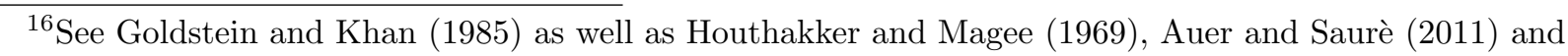
Senjadji and Montenegro (प.9.9) who also find exchange rate elasticities for Switzerland which are rather low compared to other countries. 
Column (2) in Table 6 shows the results when the data is disaggregated by export destination. The mean group estimates reported in column 2 are unweighted averages of the bilateral estimates. Compared to the aggregate estimates (shown in column (1)), the average short-term demand elasticity is substantially smaller and the average short-term exchange rate elasticity is larger when we take cross-country heterogeneity into account. The long-run elasticities are more in line with the aggregate estimates.

The results change further when, in addition, the cross-sectoral heterogeneity is taken into account (column (3)). For the exchange rate, the short-run and long-run elasticities are very similar to those reported in column (2). The differences are more substantial for the demand elasticities. The long-run demand elasticity (1.29) is the lowest of the three estimates, while the short-run elasticity (1.50) is somewhat larger than for model (2), but still considerably lower than in the aggregate data.

\subsection{Heterogeneity of elasticities}

Figure $\mathbb{U}$ shows the distribution of the long-run elasticities estimated at the sectoral and country level, i.e. the individual coefficients' estimate that are behind the averages listed in column (3) of Table [6. We only provide the distributions for the long-run estimates, since the distributions for the short-run estimates are very similar. The median of the demand elasticities (0.86) is closest to the weighted average shown in Table 6 . The median exchange rate elasticity is somewhat larger (0.86) than the weighted average. Both distributions are skewed to the left. However, the distribution of the long-run exchange rate elasticities is much tighter than the distribution of the long-run demand elasticities. The standard deviations amount to 0.55 and 2.60 , respectively. This can be explained by the fact that the real exchange rate variable has both a destination and a sector specific dimension, since the domestic price index varies across export sectors and the foreign price index across countries. Foreign GDP, by contrast, is only destination specific and has no sectoral dimension. Thus, by construction, the exchange rate variables are able to capture variations in exports across sectors while the GDP variables are not. As a result, the estimates for the exchange rate elasticities $\beta_{j i}$ are clustered fairly closely. Sector specific reactions to foreign GDP, captured by $\gamma_{j i}$, are much more dispersed.

\subsection{Differences across sectors and countries}

How much of the variation of the coefficients can be explained by systematic differences across countries and across sectors? In order to answer this question we regress the elasticities on a set of sectoral dummies and a set of country dummies, first separately and then in combination. The results are reported in Table $\boldsymbol{\nabla}$.

For the exchange rate elasticity, the sectoral structure matters, whereas the geographical composition does not. The estimation results show that the sectoral dummies explain a substantial part of the variation in exchange rate elasticities (first two columns of Table च). The adjusted R-squared is around 0.36 for the long-run and 0.57 for the short-run elasticity. In contrast, country dummies do not explain any variation of exchange rate elasticities; 
Figure 1: Distribution of long-run exchange rate and demand elasticities

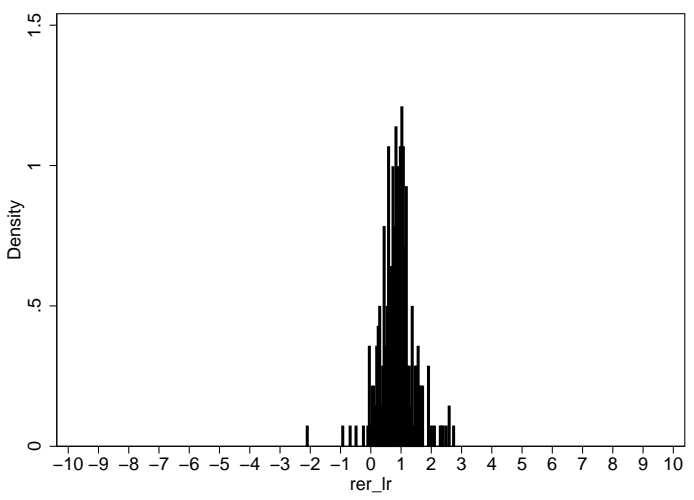

(a) Exchange rate elasticity

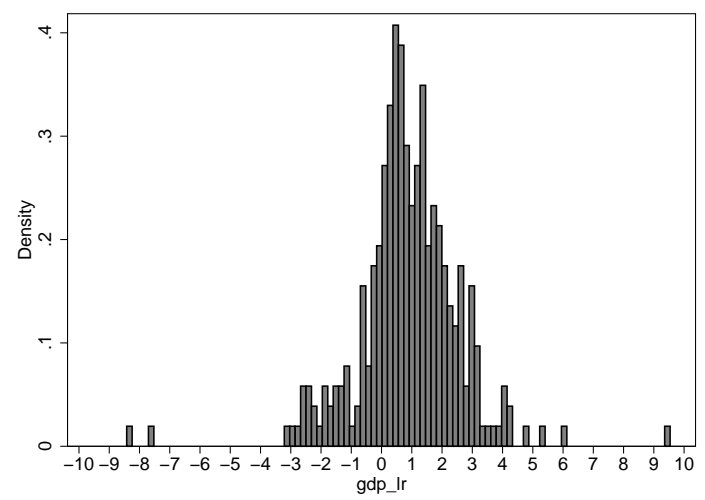

(b) Demand elasticity

Note: The figures show distributions of the estimated elasticities of exports to exchange rate and demand. Each elasticity in Figure (a) is the estimate of $\beta_{j i}^{l r}$ for sector $j$ in country $i$. There are 12 sectors and 24 countries. Analogously, Figure (b) shows the estimates of $\gamma_{j i}^{l r}$. The long-run GDP elasticity for Agricultural exports to Japan is excluded because it is an extreme outlier $\left(g d p^{l r}=34\right)$.

and adding them to the sectoral dummies does not improve the adjusted R-squared. This suggests that exchange rate elasticities are very much sector-specific, whereas there is no systematic pattern across destinations. These sector-specific characteristics may, for instance, represent differences in market power or product quality between sectors, which are independent of the destination country.

For the demand elasticity, both the geographical and sectoral structure matter. How-

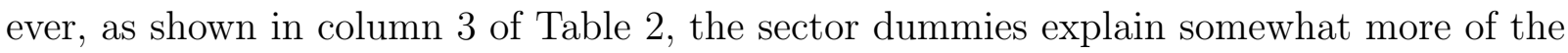
variation than the country dummies. Together, they account for about $39 \%$ of the variation in the long-run demand elasticities. For the short-run demand elasticities, however, the explanatory power of the two sets of dummies is weaker.

Table 2: Adjusted $R^{2}$

\begin{tabular}{l|cccc} 
& rer $^{l r}$ & rer $^{s r}$ & $g d p^{l r}$ & $g d p^{s r}$ \\
\hline Sector dummies & 0.358 & 0.566 & 0.224 & 0.110 \\
Country dummies & -0.011 & -0.020 & 0.163 & 0.040 \\
Sector \& country dummies & 0.364 & 0.586 & 0.392 & 0.161 \\
\hline
\end{tabular}

Note: We regress the estimated elasticities $\beta_{j i}^{l r}, \beta_{j i}^{s r}, \gamma_{j i}^{l r}$ and $\gamma_{j i}^{s r}$ on a set of sector and a set of country dummies, separately and combined. The table shows the adjusted $R^{2}$ of these regressions.

A more detailed illustration of the estimates is provided in Figure $\mathbb{B}$ in the Appendix, which contains a scatter plot of the country-specific long-run elasticities for each sector. 
Exchange rate elasticities are reported on the vertical, demand elasticities on the horizontal axis. Thus, each sector-country combination is represented by one data point. The variation of the coefficients across countries and sectors is substantial. For instance, exports to China and India are very exchange rate sensitive for chemicals incl. pharmaceuticals while their exchange rate sensitivity for the category precision instruments, watches and jewellery is very low. ${ }^{\square}$ There are also fairly systematic patterns. Exports to Italy, for instance, tend to have a fairly low exchange rate elasticity in many sectors. Meanwhile, the BRIC countries are amongst those with high demand elasticities. In the next section, we will analyse these sector- and country-specific coefficients in more detail.

\section{Elasticities at the sectoral and country level}

In this section, we document our results at the disaggregate level in more detail. We first examine unweighted means for countries and sectors and have a look at how the elasticities correlate with the Swiss export structure (section 4.1-4.3). We then analyse whether the disaggregated elasticities are systematically driven by geographical factors (section 4.4 ).

\subsection{Elasticities at the sectoral level}

Panel (a) of Figure $\nabla$ plots the short-run exchange rate elasticity against the long-run exchange rate elasticity at the sectoral level. The regression line has a positive slope, implying that the sectors which have a relatively high sensitivity to exchange rate fluctuations in the short run also have a relatively high sensitivity in the long run as well. Sectors can be classified into four groups.

- Group 1: Very low exchange rate elasticity: vehicles

- Group 2: Relatively low exchange rate elasticity: chemicals incl. pharmaceuticals

- Group 3: Average exchange rate elasticity: machinery; precision instruments, watches and jewellery.

- Group 4: Relatively high exchange rate elasticity: agriculture; paperware; textile and clothing; metals; energy; plastics and leather; stones.

Panel (b) of Figure $\nabla$ shows the sectoral short- and long-run elasticities with respect to foreign demand. In this case there is no systematic pattern. If anything, the correlation is slightly negative. This suggests that sectors which are more sensitive to business cycle fluctuations tend to react less to long-term growth trends.

Table 13 ranks the estimated elasticities in descending order. Exports of the three largest export sectors, i.e. chemicals incl. pharmaceuticals, precision instrument and watches,

\footnotetext{
${ }^{17}$ We denote the goods category precision instruments, watches and jewellery mostly with precision instruments and watches.
} 
and machinery, which make up around three quarters of Switzerland's goods exports, are relatively insensitive to exchange rate movements both in the short and long run. At the same time, the first two of these export sectors are also relatively sensitive to long-run movements in foreign demand.

These findings help to understand the relatively strong performance of Swiss exports in the past decade, even during the financial crisis and despite the marked appreciation of the Swiss franc. Exports of watches and pharmaceuticals have grown rapidly in the past decade, as they benefitted strongly from the growth in major export markets and, at the same time, have been fairly insensitive to the real appreciation of the Swiss Franc. With an export share of close to $60 \%$, these two export sectors drive overall export developments. Furthermore, the findings may also add to the question why the large trade surplus in Switzerland has hardly declined, despite the strong appreciation. The two sectors pharmaceuticals and watches are responsible for the trade surplus ${ }^{\square}$ and, according to our results, their exports are rather insensitive to exchange rate movements.

Figure 2: Correlation between long-run and short-run elasticities: by sector

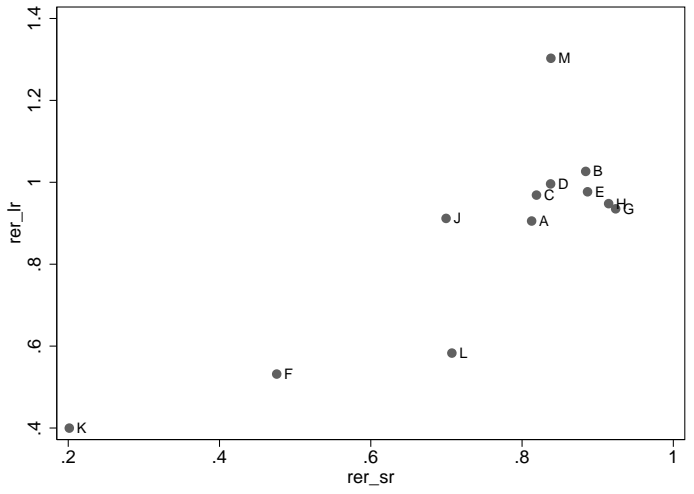

(a) Exchange rate elasticity

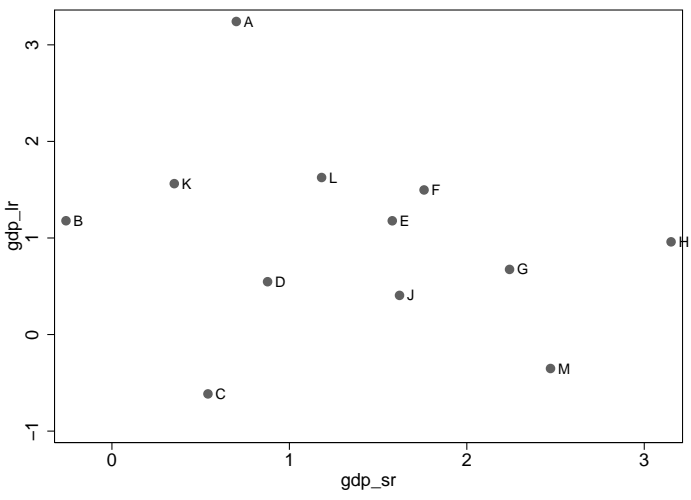

(b) Demand elasticity

Note: The figures show the correlation between the long-run and short-run elasticities of exports to (a) the exchange rates and (b) demand. Elasticities are unweighted averages across countries.

A: agriculture; B: energy; C: textiles, clothing; D: paperware; E: plastics, leather; F: chemicals incl. pharmaceuticals; G: stones; H: metals; J: machinery; K: vehicles; L: precision instruments, watches and jewellery and M: others.

\subsection{Elasticities at the country level}

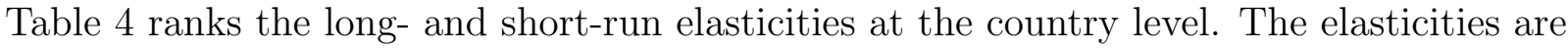
unweighted averages across sectors. China has the largest long-run and short-run exchange

\footnotetext{
${ }^{18}$ In fact, 9 of the 12 sectors have a trade deficit, i.e. only pharmaceuticals, watches and machinery have a trade surplus. The surplus of machinery, however, i negligibly small.
} 
Table 3: Long-run and short-run elasticities, by destination country

\begin{tabular}{|c|c|c|c|}
\hline \multicolumn{4}{|c|}{ Long-run elasticities } \\
\hline SECTOR & $r e r^{l r}$ & SECTOR & $g d p^{l r}$ \\
\hline Other & 1.30 & Agriculture & 3.24 \\
\hline Energy & 1.03 & Precision instr., watches & 1.63 \\
\hline Paperware & 1.00 & Vehicles & 1.56 \\
\hline Plastics, leather & 0.98 & Chemicals & 1.50 \\
\hline Textiles, clothes & 0.97 & Energy & 1.18 \\
\hline Metals & 0.95 & Plastics, leather & 1.18 \\
\hline Stones & 0.94 & Metals & 0.96 \\
\hline Machinery & 0.91 & Stones & 0.67 \\
\hline Agriculture & 0.91 & Paperware & 0.55 \\
\hline Precision instr., watches & 0.58 & Machinery & 0.41 \\
\hline Chemicals & 0.53 & Other & -0.35 \\
\hline Vehicles & 0.40 & Textiles, clothes & -0.61 \\
\hline \multicolumn{4}{|c|}{ Short-run elasticities } \\
\hline SECTOR & $r e r^{s r}$ & SECTOR & $g d p^{s r}$ \\
\hline Stones & 0.92 & Metals & 3.15 \\
\hline Metals & 0.91 & Other & 2.47 \\
\hline Plastics, leather & 0.89 & Stones & 2.24 \\
\hline Energy & 0.88 & Chemicals & 1.76 \\
\hline Other & 0.84 & Machinery & 1.62 \\
\hline Paperware & 0.84 & Plastics, leather & 1.58 \\
\hline Textiles, clothes & 0.82 & Precision instr., watches & 1.18 \\
\hline Agriculture & 0.81 & Paperware & 0.88 \\
\hline Precision instr., watches & 0.71 & Agriculture & 0.70 \\
\hline Machinery & 0.70 & Textiles, clothes & 0.54 \\
\hline Chemicals & 0.48 & Vehicles & 0.35 \\
\hline Vehicles & 0.20 & Energy & -0.26 \\
\hline
\end{tabular}

Note: Elasticities are unweighted averages across countries.

rate elasticity while Italy has the lowest (and second-lowest) exchange rate elasticities (column 1 and 3). Germany, the most important trading partner, has the lowest short-run exchange rate elasticity (column 3) and also a relatively low long-run exchange elasticity. However, there are countries (such as France and Denmark) which rank among the highest for the long-run exchange rate elasticities, but among the lowest for the short-run exchange rate elasticites. The ranking result suggests that exports to China react immediately to exchange rate movements, while exports to France and Denmark react only with a lag.

A closer look at the disaggregate estimates reveals that the short-run exchange rate elasticities for Germany are much lower than for China for four sectors: chemicals incl. pharmaceuticals, machinery, textiles and clothing, and paperware. Except for machinery, 
this finding also holds for the long-run exchange rate volatility. The type of goods that are exported to Germany versus China may explain a part of the difference. If differentiated goods dominate exports to Germany, it might be difficult for importers to substitute away from these goods.

Table 1 also shows, that exports to emerging markets such as China, Brazil, Russia, and Mexico are characterised by relatively high long-run demand elasticities. China and Brazil have elasticities of around 2. The results suggest that exports to emerging countries are relatively more GDP-sensitive than exports to other countries. This is important: as these countries experienced very high GDP growth, Swiss exports have profited a great deal from the expansion in these countries. A formal test whether different country groups have significantly different elasticities is provided in subsection 4.4 .

Table 4: Size of long and short run elasticities sorted by country

\begin{tabular}{lcll|llll}
\multicolumn{5}{c}{ Long-run elasticities } & \multicolumn{4}{c}{ Short-run elasticities } \\
COUNTRY & $r e r^{l r}$ & COUNTRY & $g d p^{l r}$ & COUNTRY & $r e r^{s r}$ & COUNTRY & $g d p^{s r}$ \\
\hline China & 1.10 & Japan & 2.52 & China & 0.90 & China & 3.35 \\
US & 1.09 & Brazil & 2.15 & Sweden & 0.85 & Spain & 2.74 \\
Poland & 1.06 & Germany & 1.98 & South Korea & 0.84 & Netherlands & 2.51 \\
Australia & 1.06 & China & 1.93 & Hong Kong & 0.82 & Italy & 2.18 \\
Spain & 1.05 & Mexico & 1.88 & Singapore & 0.81 & Germany & 1.92 \\
France & 1.00 & Russia & 1.59 & Mexico & 0.80 & US & 1.84 \\
Denmark & 0.96 & Canada & 1.27 & India & 0.79 & France & 1.80 \\
Greece & 0.95 & US & 1.21 & Australia & 0.79 & Poland & 1.79 \\
Brazil & 0.95 & Spain & 1.16 & Canada & 0.78 & Greece & 1.72 \\
Mexico & 0.91 & South Korea & 1.09 & Japan & 0.78 & Russia & 1.61 \\
Canada & 0.91 & India & 1.08 & Brazil & 0.78 & Mexico & 1.14 \\
UK & 0.89 & Italy & 0.96 & Netherlands & 0.76 & India & 1.11 \\
Sweden & 0.88 & France & 0.85 & Greece & 0.75 & Austria & 1.05 \\
Hong Kong & 0.85 & Netherlands & 0.83 & Spain & 0.74 & Denmark & 0.94 \\
India & 0.84 & Australia & 0.78 & Poland & 0.74 & UK & 0.92 \\
South Korea & 0.83 & Poland & 0.77 & US & 0.74 & Sweden & 0.90 \\
Russia & 0.83 & UK & 0.68 & Russia & 0.72 & Belgium & 0.83 \\
Singapore & 0.82 & Singapore & 0.56 & Belgium & 0.70 & Hong Kong & 0.74 \\
Netherlands & 0.76 & Greece & 0.41 & Austria & 0.69 & Singapore & 0.72 \\
Japan & 0.70 & Belgium & 0.39 & UK & 0.68 & Japan & 0.69 \\
Germany & 0.69 & Hong Kong & 0.36 & France & 0.67 & South Korea & 0.59 \\
Belgium & 0.64 & Sweden & 0.15 & Denmark & 0.65 & Brazil & 0.59 \\
Austria & 0.63 & Austria & 0.15 & Italy & 0.61 & Canada & 0.42 \\
Italy & 0.60 & Denmark & -0.95 & Germany & 0.59 & Australia & 0.32 \\
\hline
\end{tabular}

Note: Elasticities are unweighted averages across sectors. 


\subsection{Elasticities and export structure}

In subsection 4.0 we found that there are clearly distinct sectoral groups in terms of exchange rate sensitivity. In this section we look at how exchange rate and foreign demand sensitivities correlate with (changes in) the Swiss export structure.

To do so, we first examine the correlations between export shares and elasticites. These correlations tell us whether larger sectors have particularly large (small) elasticites and thereby help us to understand elasticites of the aggregate. Secondly, we examine the correlations between the change in export shares and elasticities, which captures structural shifts between sectors and export markets. These correlations tell us whether exports have grown more strongly if exchange rate elasticities are low and foreign demand elasticities are large. One might expect that sectors that are less sensitive to exchange rate changes have gained market share. ${ }^{\mathbb{1}}$ Similarly, exports with high demand elasticities, in particular to fast growing emerging markets, can be expected to have grown in importance.

There seems to be no significant relationship between export shares and exchange rate elasticities. Panel (a) in Figure B plots the short-run exchange rate elasticities and export shares for each individual export sector. ${ }^{\text {⿴囗口 }}$ Panel (b) does the same with long-run exchange rate elasticities. The small negative correlation is essentially driven by the chemicals incl. pharmaceutical sector alone. For sectoral demand elasticities (not shown) the correlation with the sector share is also very weak.

Exports in sectors with high exchange rate elasticities have decreased over time. However, the evidence for that is not very strong. Figure $\mathbb{\theta}$ plots the average exchange rate elasticities against the change in export shares between 1988 and 2014. The change in shares is defined as the log ratio of the export share at the beginning (average of 19881990) and at the end (2012-2014) of the sample. We use this measure as it gives a smaller weight to the growth of very small sectors that have much more potential to grow than sectors that are already large. Both charts of Figure $\mathbb{\theta}$ do indeed display a negative but statistically non-significant relationship between the magnitude of the exchange rate elasticities and the change in export shares.

The link between long-run foreign demand elasticities and the change in export shares appears to be closer (panel b) in Figure ( ). In fact, $75 \%$ of the cross-sectoral variation in the change in export shares can be explained by the size of the demand elasticity. This implies that sectors with a relatively high long-run demand elasticity have seen their share in total exports increase. Interestingly, the slope of the relation is slightly negative in panel (a) of Figure 5 while it is strongly positive in panel (b). In other words, export sectors which benefit more from longer-term demand trends have gained in importance, while exports that are more vulnerable/exposed to foreign business cycle fluctuations have somewhat become less important.

\footnotetext{
${ }^{19}$ Note that basically across all sectors and trading partners, the Swiss franc has appreciated in real terms during the considered time span.

${ }^{20}$ Our measure of the share is a three year average (2012-2014) in terms of the countries included in the sample for this paper.
} 
Turning now to the country specific estimates, we find a negative significant relationship between the export shares and the short-run exchange rate elasticities (result not shown). This implies that the most important destination markets have lower short-run exchange rate elasticities. Moreover, as in Figure [ shows, we can identify a weakly significant relationship between the two long-run demand elasticities and the change in the export share $\left(R^{2}=0.22\right.$ and $\left.R^{2}=0.19\right)$. This suggests that exports to countries with higher long-run demand elasticities expanded more strongly. At the same time, these countries have also higher long-run exchange rate elasticities.

Figure 3: Share of exports and exchange rate elasticities: by sector

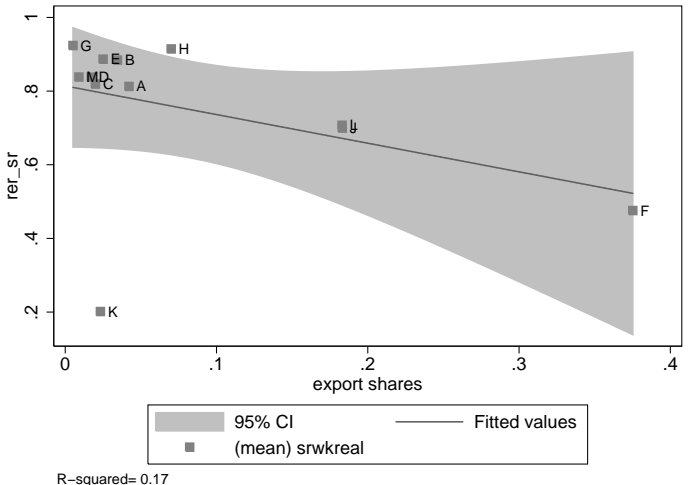

(a) Short-run exchange rate elasticity

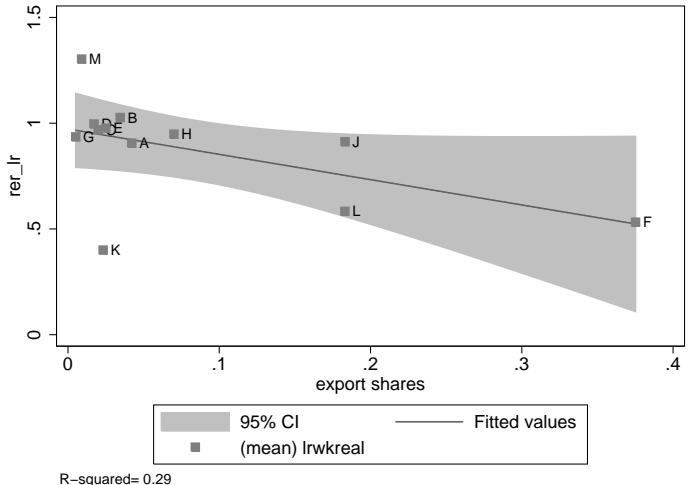

(b) Long-run exchange rate elasticity

Note: The figures show the estimated elasticities of exports to exchange rates and foreign demand for each sector.

A: agriculture; B: energy; C: textiles, clothing; D: paperware; E: plastics, leather; F: chemicals incl. pharmaceuticals; G: stones; H: metals; J: machinery; K: vehicles; L: precision instruments, watches and jewellery and M: others. 
Figure 4: Change in the share of exports and exchange rate elasticities: by sector

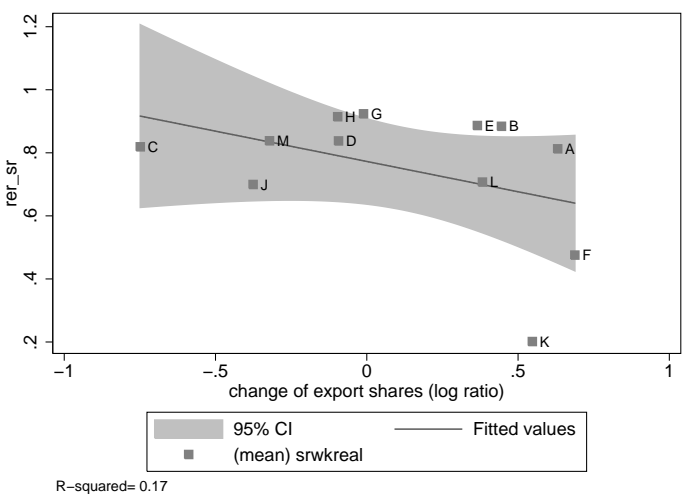

(a) Short-run exchange rate elasticity

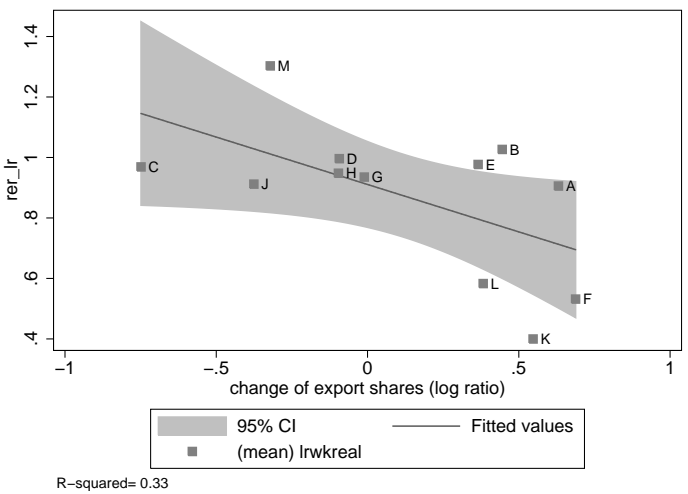

(b) Long-run exchange rate elasticity

Note: The figures show the estimated elasticities of exports to exchange rates and foreign demand for each sector.

A: agriculture; B: energy; C: textiles, clothing; D: paperware; E: plastics, leather; F: chemicals incl. pharmaceuticals; G: stones; H: metals; J: machinery; K: vehicles; L: precision instruments, watches and jewellery and M: others.

Figure 5: Change in the share of exports and GDP elasticities: by sector

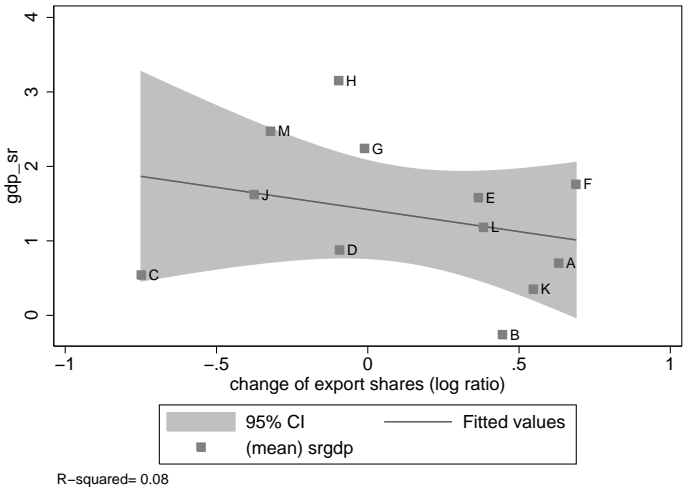

(a) Short-run demand elasticity

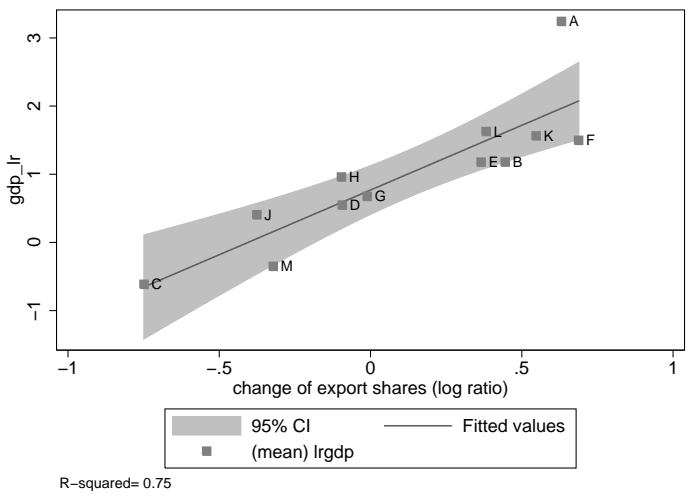

(b) Long-run demand elasticity

Note: The figures show the estimated elasticities of exports to exchange rates and foreign demand for each sector.

A: agriculture; B: energy; C: textiles, clothing; D: paperware; E: plastics, leather; F: chemicals incl. pharmaceuticals; G: stones; H: metals; J: machinery; K: vehicles; L: precision instruments, watches and jewellery and M: others. 
Figure 6: Change in the share of exports and long-run elasticities: by country

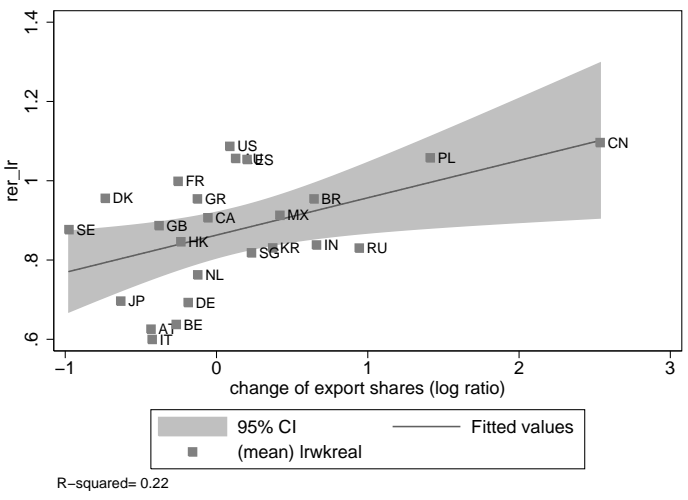

(a) Exchange rate elasticity

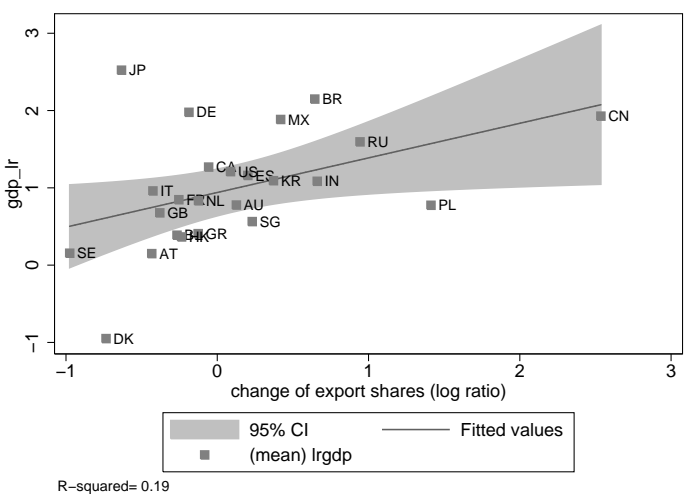

(b) Demand elasticity

Note: The figures show the estimated elasticities of exports to exchange rates and foreign demand for each country.

AT: Austria, AU: Australia, BG: Belgium, BR: Brazil, CA: Canada, CN: China, DE: Germany, DK: Denmark, ES: Spain, FR: France, GB: United Kingdom, GR: Greece, HK: Hong Kong, IN: India, IT: Italy, JP: Japan, KR: South Korea, MX: Mexico, NL: Netherlands, PL: Poland, RU: Russia, SE: Sweden, SG: Singapore, US: United States

\subsection{Geographical patterns in elasticities}

In subsection 4.2, we found that Swiss exports to emerging markets have relatively high long-run GDP elasticities. In this section, we provide a formal test whether Swiss exports to certain groups of countries have significantly different elasticities from each other. Using dummies, we focus on three sets of geographic characteristics: common border, euro area and emerging markets. ${ }^{\text {W }}$ The set of dummies are selected by the importance for Switzerland (common border and euro area) and most dynamic countries (emerging markets). The other countries are the reference group.

Overall, the results are mixed. For the exchange rate, the long-run elasticities are not significantly higher or lower for any of the country groups (see Table $\mathbf{5}$, column 1). Only the short-run elasticities are slightly larger for emerging markets (column 2).

For foreign demand, the long-run elasticities are significantly higher for emerging markets than for the rest (column 3), by around 0.6pp. For short-run demand elasticities, the only significant difference relates to the euro area (column 4). Here the elasticities are 1pp larger. These results confirm that Swiss exports benefited more strongly from long-term growth in emerging markets. At the same time they are affected more strongly by shortrun demand fluctuations in the euro area which is (in terms of their export shares) an important destination market for Switzerland.

\footnotetext{
${ }^{21}$ We categorize the following countries as emerging markets: China, Hong Kong, Singapore, India, Brazil, Mexico, Russia and Poland.
} 
Table 5: Geographical determinants of estimated elasticities

\begin{tabular}{lcccc} 
& $(1)$ & $(2)$ & $(3)$ & $(4)$ \\
VARIABLES & rer $^{l r}$ & rer $^{s r}$ & $g d p^{l r}$ & $g d p^{s r}$ \\
\hline euroarea & -0.07 & -0.00 & 0.25 & $1.00^{* * *}$ \\
& $(0.08)$ & $(0.03)$ & $(0.24)$ & $(0.30)$ \\
emergingmarket & 0.08 & $0.06^{*}$ & $0.62^{* * *}$ & 0.47 \\
& $(0.07)$ & $(0.03)$ & $(0.19)$ & $(0.31)$ \\
border & -0.02 & -0.08 & 0.08 & -0.00 \\
& $(0.12)$ & $(0.07)$ & $(0.29)$ & $(0.27)$ \\
Constant & $0.86^{* * *}$ & $0.76^{* * *}$ & $0.53^{* *}$ & $0.97^{* * *}$ \\
& $(0.09)$ & $(0.07)$ & $(0.21)$ & $(0.27)$ \\
\hline Observations & 288 & 288 & 288 & 288 \\
R-squared & 0.03 & 0.03 & 0.05 & 0.04 \\
\hline
\end{tabular}

Note: Coefficients are reported with standard errors clustered by sectors in parantheses. Significance levels are denoted by ${ }^{* * *}=p<0.01 ;^{* *}=p<0.05 ;^{*}=p<0.1$.

A possible explanation for the latter finding could be the importance of the globalisation of the value added chain, in particular with the euro area. Because of lower transportation costs (distance and time), reliability and cultural similarities, a lot of the final goods exported from Switzerland might be partly assembled in the euro area, and then reimported to Switzerland. As a result, the effect of a rise or drop in demand for these goods on Swiss exports is multiplied, whereas the effect on Swiss value added would be limited.

\section{Robustness}

There is a debate on whether the exchange rate volatility affects exports. For instance, de Vita_and Abbott (20104) find no short-run effect, but the long-run volatility seems to impact UK exports to EU countries. Broda and Romalis (201]) points to an endogeneity problem but still finds some small effects, and also Byrne et al. (2008) figures out some negative effects. In contrast, Tenreyro (2007) finds no significant impact of nominal exchange rate volatility on trade flows by looking at a broad sample of countries.

On the one hand, we included the nominal exchange rate volatility ${ }^{\mathbb{Z}}$ into the shortrun relationship. On the other hand, we included the volatility measure into the longrun relationship. We do not find evidence that the short-run elasticity of the volatility measure affects exports significantly. In addition, we find that for most of our bilateral and

\footnotetext{
${ }^{22}$ We used the moving standard deviation of the log first difference of bilateral daily (and monthly) exchange rates across one months (and one year) and then took the average in order to obtain a quarterly measure.

${ }^{23}$ Chowdhury ([0993) suggests that exchange rate volatility affects trade through the long-run relationship.
} 
sectoral estimations there is also no significant long-run effect of the exchange rate volatility on exports. We only find for a few sectors and countries that the long-run elasticity of the volatility is significant. Including the volatility in our regressions does hardly change our results for the exchange rate elasticity. Some changes are observed concerning the GDP elasticities. However, the broad picture of our results presented below do not change if we take the exchange rate volatility into account.

Table [ compares the weighted average of our single regressions without (column (3) in Table [) and with the exchange rate volatility in the long-run relationship. The results for the average elasticities do remain basically unchanged. Figures $\square$ plot the sectoral average elasticity of the two approaches against each other.

Table 6: Elasticities with and without exchange rate volatility

\begin{tabular}{lcc} 
& without & with \\
& exchange rate volatility & exchange rate volatility \\
\hline$r e r^{l r}$ & $0.76^{* * *}$ & $0.72^{* * *}$ \\
& $(0.44)$ & $(0.42)$ \\
$g d p^{l r}$ & $1.29^{* * *}$ & $1.26^{* * *}$ \\
& $(1.20)$ & $(1.00)$ \\
ervola ${ }^{l r}$ & & 1.15 \\
& & $(14.89)$ \\
$r e r^{s r}$ & $0.64^{* * *}$ & $0.64^{* * *}$ \\
& $(0.07)$ & $(0.07)$ \\
$g d p^{s r}$ & $1.50^{* *}$ & $1.55^{* *}$ \\
& $(1.42)$ & $(1.47)$ \\
$\lambda_{j i}$ & $0.21^{* * *}$ & $0.23^{* * *}$ \\
& $(0.06)$ & $(0.06)$ \\
\hline Method & Panel & Panel \\
Estimated by & Country and sector & Country and sector
\end{tabular}

Note: Coefficients are reported with clustered standard errors in parentheses. Significance levels are denoted by ${ }^{* * *}=p<0.01 ; * *=p<0.05 ;^{*}=p<0.1$. The significance level refers to the weighted average of individual t-values while the standard errors reported are weighted averages of standard errors.

\section{Conclusion}

To gain a deeper understanding of the heterogeneity across sectors and export markets, this paper has analysed the sensitivity of Switzerland's exports to changes in foreign GDP and exchange rates at both the sectoral and the export country level.

We find that the two largest export sectors (chemicals incl. pharmaceuticals, precision instruments and watches) are relatively insensitive to exchange rate changes. At the same time, they are relatively sensitive to long-run changes in foreign GDP. In addition, sectors 
Figure 7: Comparison of estimated elasticities

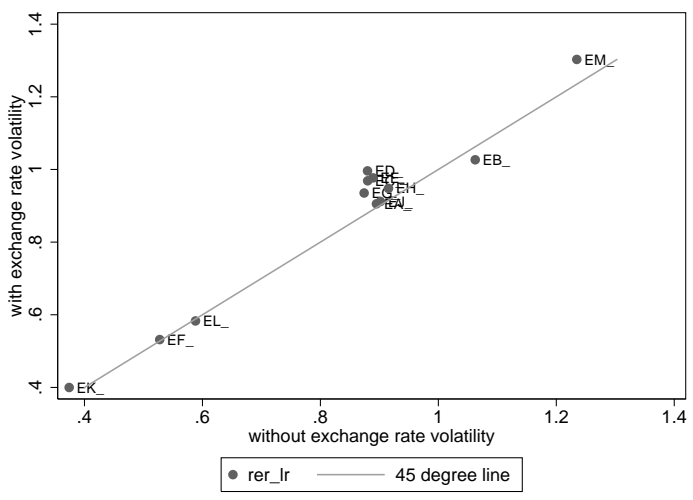

(a) Exchange rate elasticity (long-run)

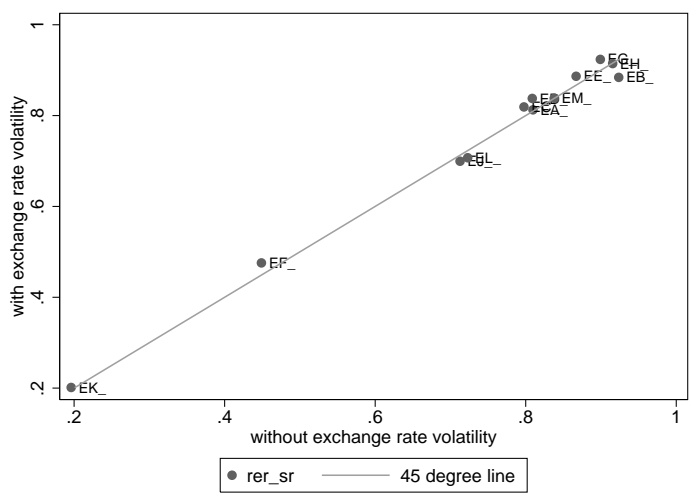

(c) Exchange rate elasticity (short-run)

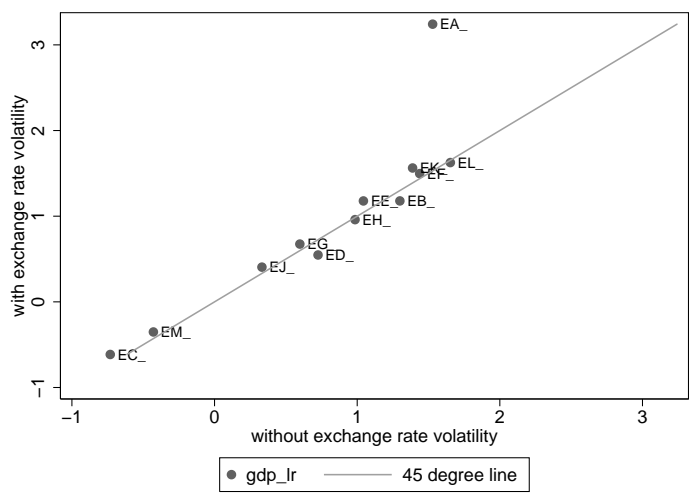

(b) Demand elasticity (long-run)

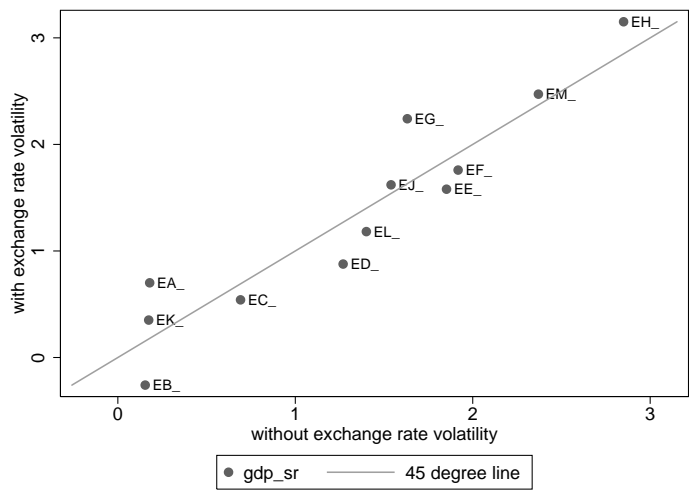

(d) Demand elasticity (short-run)

A: agriculture; B: energy; C: textiles, clothing; D: paperware; E: plastics, leather; F: chemicals incl. pharmaceuticals; G: stones; H: metals; J: machinery; K: vehicles; L: precision instruments, watches and jewellery and M: others.

with high long-run demand elasticities have seen their export shares rise. The same applies to export destinations: exporters have shifted towards markets with higher long-run demand elasticities. Overall, our findings suggest that long-run foreign demand developments are more important for structural considerations than exchange rate elasticities.

While Swiss exports are relatively more sensitive to long-run demand trends in emerging markets, they are relatively more sensitive to short-run demand fluctuations in the euro area. This makes Switzerland's exports vulnerable to negative foreign demand shocks originating from the most important destination countries. At the same time Swiss exports have profited a great deal from emerging economies. The shift of exports towards markets with higher GDP growth (emerging markets) and the relative robustness of large sectors 
to changes in the exchange rate explains why Switzerland's exports were fairly resilient during the recent crisis. Nevertheless, it has to be kept in mind, however, that the lasting weakness of the European economy and the distinctive exchange rate shock are still leaving deep marks on Swiss export developments. 


\section{References}

Abrahamsen, Y. And B. Simmons-SüER (2011): "Die Wechselkursabhängigkeit der Schweizer Wirtschaft," KOF Studien Nr. 24, KOF Konjunkturfoschungsstelle, ETH, Zurich.

Auer, R. AND P. SAurè (2011): "Export basket and the effects of exchange rates on exports: why Switzerland is special," Globalization and Monetary Policy Institute Working Paper 77, Federal Reserve Bank of Dallas.

(2012): "CHF strength and Swiss export performance - evidence and outlook from a disaggregate analysis," Applied Economics Letters, 19, 521-531.

Broda, C. And J. Romalis (2011): "Identifying the Relationship Between Trade and Exchange Rate Volatility," in Commodity Prices and Markets, East Asia Seminar on Economics, Volume 20, National Bureau of Economic Research, Inc, NBER Chapters, $79-110$.

Byrne, J., J. Darby, And R. MacDonald (2008): "US trade and exchange rate volatility: A real sectoral bilateral analysis," Journal of Macroeconomics, 30, 238-259.

Chowdhury, A. (1993): "Does exchange rate volatility depress trade flows? Evidence from error-correction models," The Review of Economics and Statistics, 75, 700-706.

DE Vita, G. And A. Aвbотt (2004): "The impact of exchange rate volatility on UK exports to EU countries," Scottish Journal of Political Economy, 51, 62-81.

Goldstein, M. And M. Khan (1985): "Income and Price Effects in Foreign Trade," in Handbook of International Economics, Jones, R.W. and P.B. Kenen (editors), vol. 1, chap. 20, 1041-1105.

Goldstein, M. And M. S. Khan (1978): "The Supply and Demand for Exports: A Simultaneous Approach," The Review of Economics and Statistics, 60, 275-286.

Hooper, P., K. Johnson, And J. Marquez (2000): "Trade elasticities for G-7 countries," Princeton Studies in International Economics 87, Department of Economics, Princeton University.

Houthakker, H. And S. Magee (1969): "Income and Price Elasticities in World Trade," The Review of Economics and Statistics, 51, 111-125.

Imbs, J. And I. Mejean (2015): "Elasticity Optimism," American Economic Journal: Macroeconomics, 7, 43-83.

Jaussaud, J. And S. Rey (2012): "Long-Run Determinants of Japanese Exports to China and the Unisted States: A Sectoral Analysis," Pacific Economic Review, 17. 
Lamla, M. And A. Lassmann (2011): "Der Einfluss der Wechselkursentwicklung auf die Schweizer Warenexporte: Eine disaggregierte Analyse," Spezialanalyse, KOF Konjunkturfoschungsstelle, ETH, Zurich.

Marquez, J. (1990): "Bilateral Trade Elasticities," Review of Economics and Statistics, $72,70-77$.

ers

Matthieu, B., G. Callegari, F. Ghironi, G. Sestieri, and N. Yamano (2013): "Estimating Trade Elasticities: Demand Composition and the Trade Collapse of 20082009," American Economic Journal: Macroeconomics, 5, 118-151.

Orcutt, G. (1950): "Measurement of Price Elasticities in International Trade," Review of Economics and Statistics, 32, 117-132.

Persyn, D. And J. Westerlund (2008): "Error Correction Based cointegration Tests for Panel Data," Stata Journal 8, 8, 232-241.

Pesaran, M. H., Y. Shin, And R. Smith (1999): "Pooled mean group estimation of dynamic heterogeneous panels," Journal of the American Statistical Association, 94, $621-634$.

Pesaran, M. H. And R. Smith (1995): "Estimating long-run relationships from dynamic heterogeneous panels," Journal of Econometrics, 68, 79-113.

SECO (2010): "Aussenhandelsentwicklung der Schweiz im Jahr 2009," Konjunkturtendenzen Frühjahr 2010, SECO, Bern.

Senjadji, A. S. And C. E. Montenegro (1999): "Time Series Analysis of Export Demand Equations: A Cross-Country Analysis," IMF Staff Papers 3, IMF.

Tenreyro, S. (2007): "On the trade impact of nominal exchange rate volatility," Journal of development economics, 82, 485-508.

WARner, D. AND M. E. Kreinin (1983): "Determinants of International Trade Flows," The Review of Economics and Statistics, 65, 96-104.

Westerlund, J. (2007): "Testing for error correction in panel data," Oxford Bulletin of Economics and Statistics, 69, 709748. 


\section{A Appendix}

\section{A.1 Export shares}

Table 7: List of countries

\begin{tabular}{llr} 
Abbreviation & Country & Export share $^{1}$ \\
\hline AT & Austria & 3.0 \\
AU & Australia & 1.2 \\
BE & Belgium & 2.5 \\
BR & Brazil & 1.1 \\
CA & Canada & 1.6 \\
CN & China & 4.0 \\
DE & Germany & 19.0 \\
DK & Denmark & 0.5 \\
ES & Spain & 2.7 \\
FR & France & 7.1 \\
GB & United Kingdom & 4.5 \\
GR & Greece & 0.5 \\
HK & Hong Kong & 3.4 \\
IN & India & 1.0 \\
IT & Italy & 7.0 \\
JP & Japan & 3.1 \\
KR & South Korea & 1.2 \\
MX & Mexico & 0.8 \\
NL & Netherlands & 2.6 \\
PL & Poland & 1.0 \\
RU & Russia & 1.4 \\
SE & Sweden & 0.7 \\
SG & Singapore & 1.7 \\
US & United States & 11.7 \\
\hline${ }^{1}$ Export share is averaged over the period $2012-2014$.
\end{tabular}


Table 8: List of sectors

\begin{tabular}{llr} 
Abbreviation & Sector & Export $^{\text {share }}$ \\
\hline A & Agriculture & 4.5 \\
B & Energy & 2.2 \\
C & Textiles, clothing & 1.5 \\
D & Paperware & 1.0 \\
E & Plastics, leather & 2.1 \\
F & Chemicals incl. pharmaceuticals & 40.2 \\
G & Stones & 0.4 \\
H & Metals & 6.0 \\
J & Machinery & 16.4 \\
K & Vehicles & 2.6 \\
L & Precision instruments, watches and jewellery & 22.4 \\
M & Other & \\
\hline
\end{tabular}

${ }^{1}$ Export share is averaged over the period 2012-2014.

${ }^{2}$ Other contains e.g. musical instruments, toys and furniture. 


\section{A.2 Panel cointegration tests}

This section reports panel cointegration tests supporting the use of an error-correction framework as our main model specification. We use the test developed in Westerlund $(\mathbb{2 0 0 7})$, which tests for cointegration allowing for heterogeneity in coefficients in the crosssection, which is closely related to the mean group estimator employed in this paper. Broadly speaking, the test estimates the same equation as we do in the main section, and then tests whether the average of the individual error-correction coefficients is significantly different from zero. We report mean-group statistics for the null hypothesis of no cointegration, setting the number of lags to one, as in our main specification. We report two statistics, one is the original statistic, $G_{\tau}$, the other is the statistic, which is normalized by the time-series dimension, $T, G_{\alpha}$.

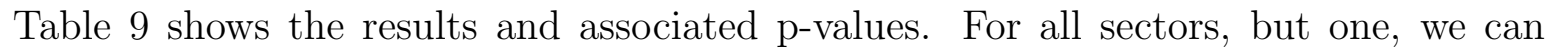
reject the null of no cointegration at the $1 \%$ level. Only for the sector textiles/clothing, we cannot reject the null at the $10 \%$ level for the statistic that does not include the correction for the time-series dimension. However, the p-value is still considerably low, suggesting that the error-correction framework is appropriate.

Table 9: Panel cointegration test

\begin{tabular}{l|rr|rr} 
Sector & $G_{\tau}$ & p-value & $G_{\alpha}$ & p-value \\
\hline Total & -3.29 & 0.00 & -22.11 & 0.00 \\
A & -2.68 & 0.00 & -16.83 & 0.00 \\
B & -4.96 & 0.00 & -47.82 & 0.00 \\
C & -2.26 & 0.11 & -11.78 & 0.02 \\
D & -3.01 & 0.00 & -20.51 & 0.00 \\
E & -3.26 & 0.00 & -21.68 & 0.00 \\
F & -3.24 & 0.00 & -20.97 & 0.00 \\
G & -3.34 & 0.00 & -24.60 & 0.00 \\
H & -3.80 & 0.00 & -22.75 & 0.00 \\
J & -3.21 & 0.00 & -19.53 & 0.00 \\
K & -3.76 & 0.00 & -25.11 & 0.00 \\
L & -2.69 & 0.00 & -16.93 & 0.00 \\
M & -3.18 & 0.00 & -19.96 & 0.00 \\
\hline
\end{tabular}


A.3 Long-run elasticities by sector and countries 
Figure 8: Elasticities across countries: by sector

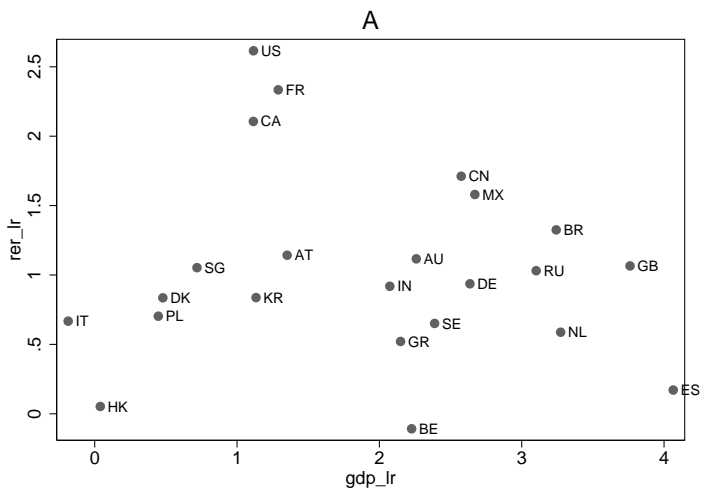

(a) Agriculture (Note: JP is excluded because $g d p^{l r}=34$.)

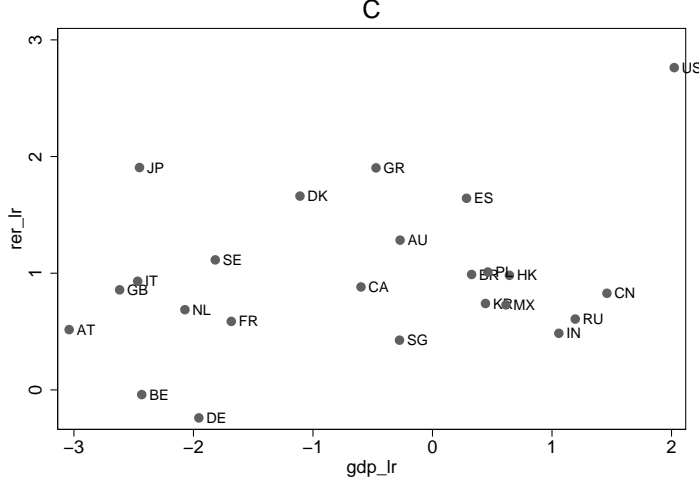

(c) Textiles, clothing

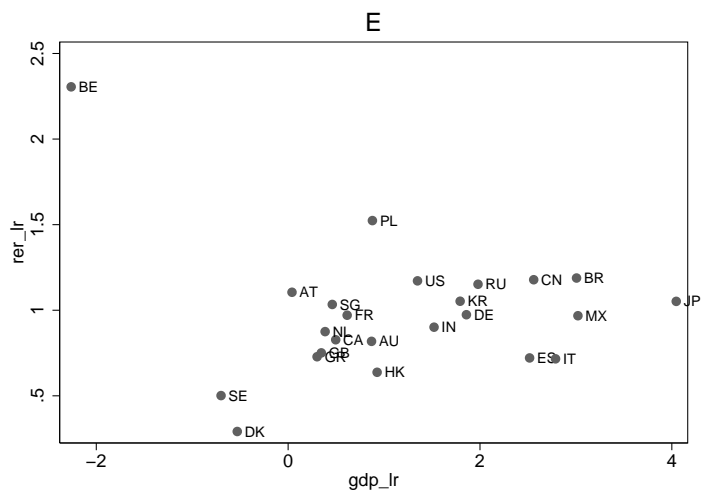

(e) Plastics, leather

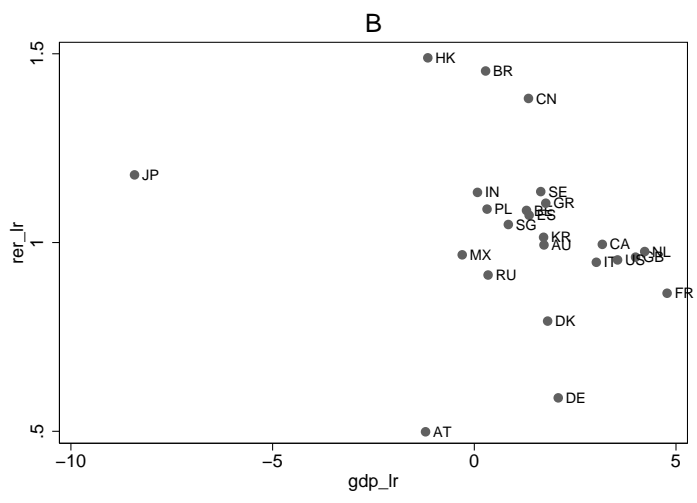

(b) Energy

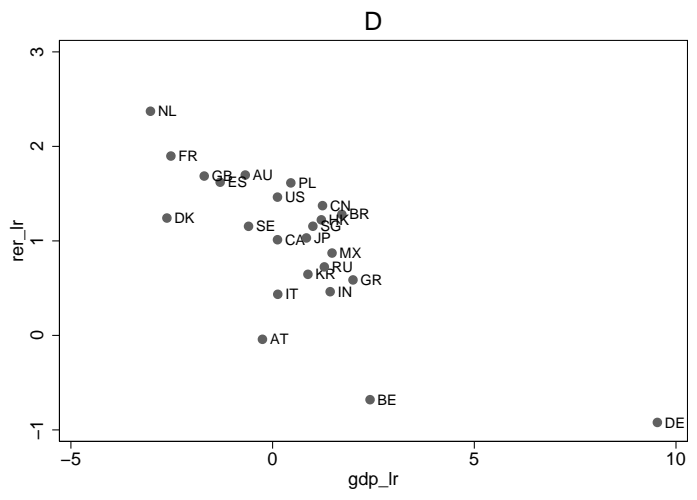

(d) Paperware

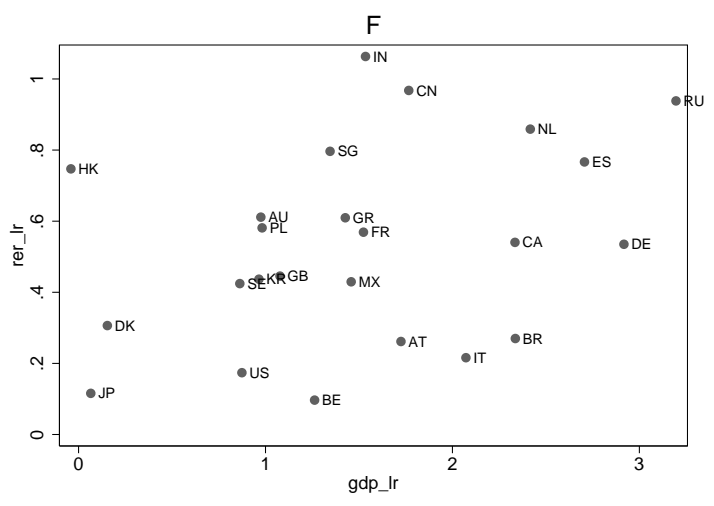

(f) Chemicals incl. pharmaceuticals 
Figure 9: Elasticities across countries: by sector contd.

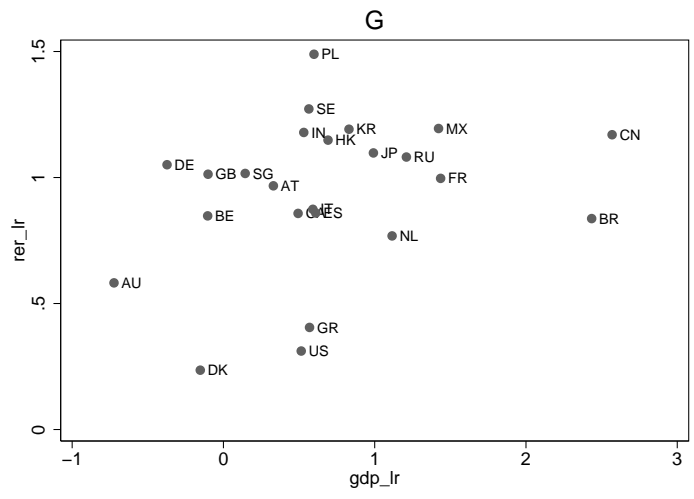

(a) Stones

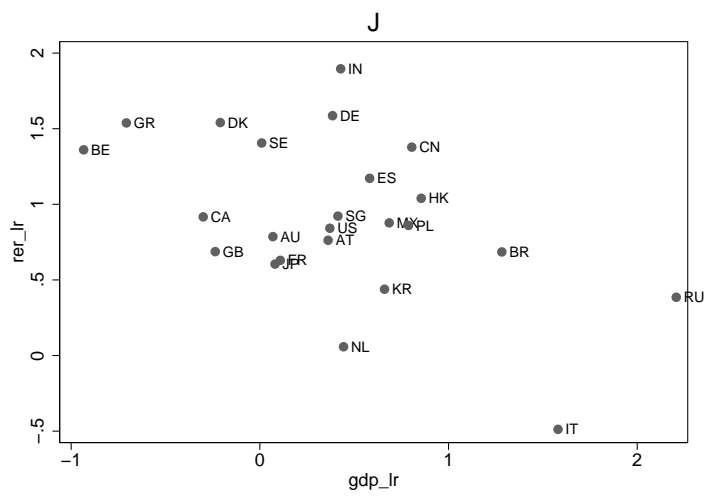

(c) Machinery

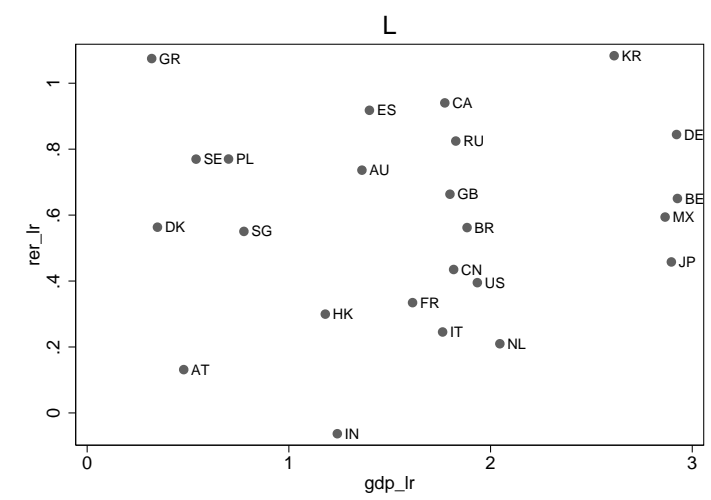

(e) Precision instruments, watches and jewellery

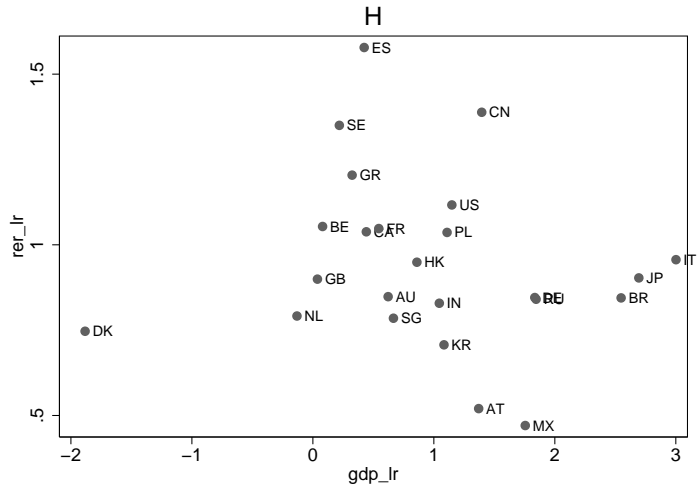

(b) Metals

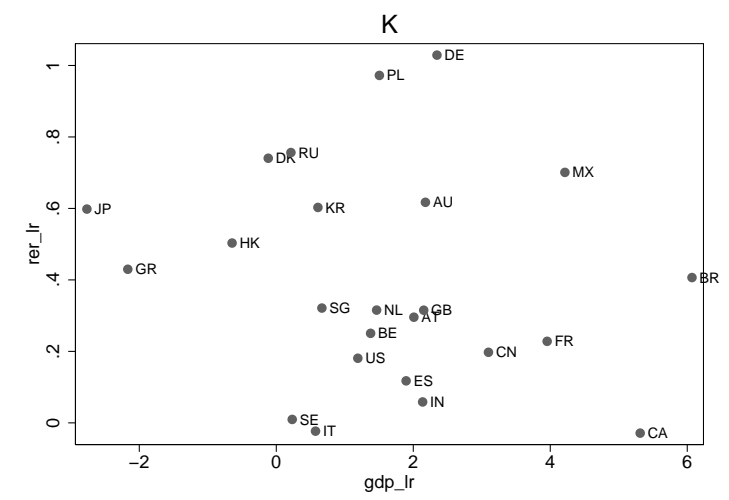

(d) Vehicles

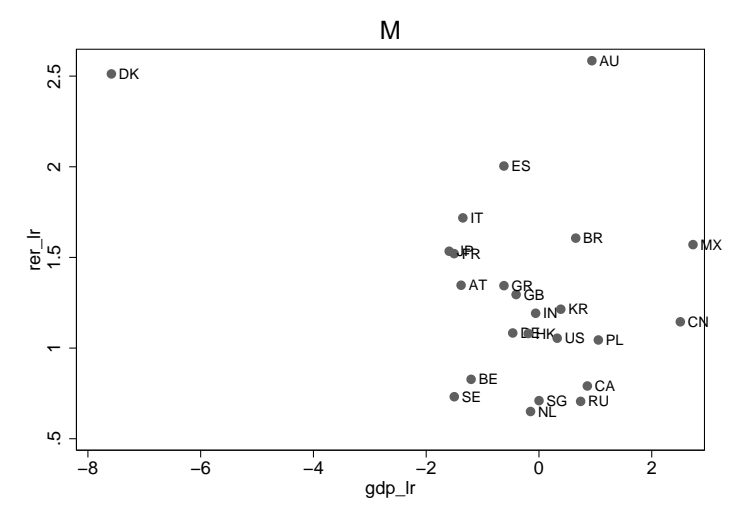

(f) Others 